\title{
100 éve született - egy éve hunyt el Dr. NAGY BARNABÁS (1921-2020)
}

\author{
SZÖVÉNYI GERGELY \\ Eötvös Loránd Tudományegyetem, Állatrendszertani és Ökológiai Tanszék \\ 1117 Budapest, Pázmány Péter sétány 1/C \\ E-mail: gergely.szovenyi@ttk.elte.hu
}

2020. június 27-én, 99 éves korában elhunyt Dr. NAGY BARNABÁS zoológus, és egy év elteltével már születésének századik évfordulójára emlékezünk. Igen hosszú, eredményekben gazdag tudományos életpályája a növényvédelmi rovartan és a közép-európai orthopterológia megkerülhetetlen alakjává tette.

NAGY BARNABÁS 1921. augusztus 2-án Szamoskéren született. Gyermekkorát az északkelet-magyarországi Alsóvadászon, majd Debrecenben töltötte. Egyetemi tanulmányai is ez utóbbi városhoz és Kolozsvárhoz kötötték. 1944-től 1949-ig, kétéves angol hadifogsággal megszakítva, a Kolozsvári, majd a Debreceni Tudományegyetemen elöször gyakornokként, később tanársegédként, zoológiai tárgyak oktatásában vett részt. 1950-ben került az MTA Növényvédelmi Kutatóintézetéhez (ma ELKH ATK NÖVI), ahol 1970 és 1978 között az Állattani Osztály vezetője volt. Nyugdíjazásáig, majd nyugalmazott tudományos tanácsadóként egészen 2013 végéig dolgozhatott itt, először a Herman Ottó úti központban, azután több mint négy évtizeden keresztül az intézet Júlia-majori telephelyén. Utolsó éveiben a Magyar Természettudományi Múzeum Állattára fogadta be, itt a Kisebb rovarrendek gyüjteményében gondozta önkéntesként, majd társult kutatóként a múzeumnak ajándékozott kb. 40000 tüzött példányból és 3000 fiolából álló, főleg egyenesszárnyúakat tartalmazó gyüjteményét, szinte élete végéig (SzŐCS et al. 2020, SzÖVÉNYI et al. 2020a).

Tudományos pályafutásának két fő vonulata volt: az egyenesszárnyú rovarok és a növényvédelmi rovartan. Mindkettőt magas szinten művelte, és noha az NKI-ban elsődlegesen ez utóbbival foglalkozott, a két kutatási terület - a sáskajárások révén - találkozott munkáiban. Pályája során mindkét tudományterület nemzetközileg jegyzett kutatójává vált. Az általa vizsgált témák közül kiemelkedő a Magyarország, valamint a tágan értelmezett Kárpát-Pannon régió és környezetének Orthoptera-faunisztikai feltárása, az egyenesszárnyúak természetvédelme, közösségi ökológiája. A növényvédelmi rovartan témakörén belül a legkülönbözőbb rovarkártevők életmódját, ökológiáját tárta fel részletesen, ezek közül a kukoricamollyal kapcsolatos kutatásai máig relevánsak. Kiemelhetők még a korában nemzetközi szinten is újdonságnak számító, radioaktív besugárzással létrehozott steril hímeken alapuló növényvédelemmel kapcsolatos kísérletei, ill. talán a legjelentősebb, ám évtizedeken keresztül fel nem ismert fontosságú megközelítési mód, a korát messze megelőzve, 1957-ben megfogalmazott ökológiai növényvédelem koncepciója (SzÖVÉNYI et al. 2020b). 


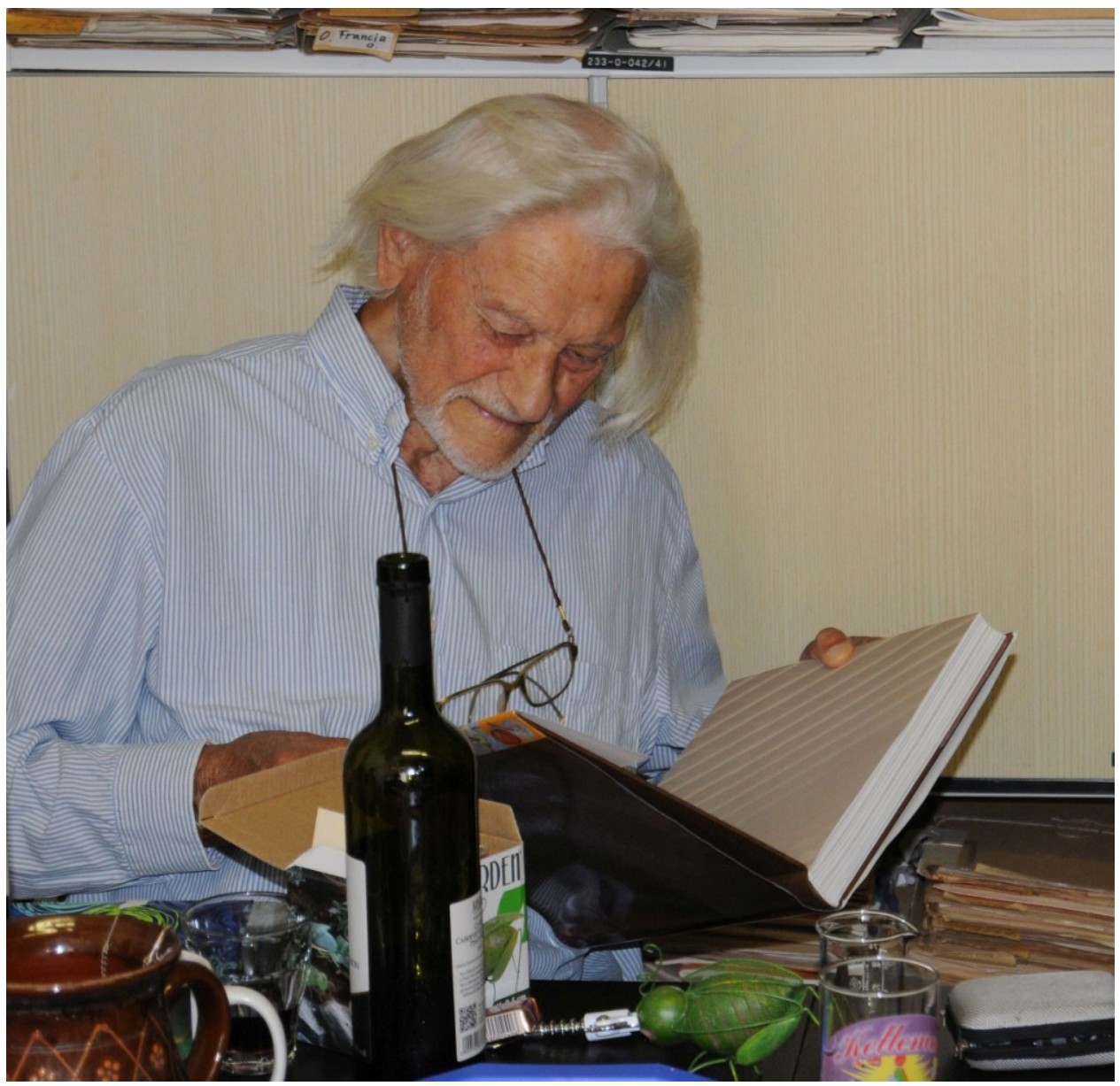

1. ábra. Dr. NAGY BARNABÁs 2016 augusztusában a Magyar Természettudományi Múzeum Állattárában ünnepelt 95 . születésnapján

Figure 1. Dr. BARNABÁS NAGY in August 2016, at the celebration of his $95^{\text {th }}$ anniversary in the Hungarian Natural History Museum

A kutatáson kívül mindvégig fontosnak tartotta a magas szintü ismeretterjesztést és az oktatást is. Vendégkutatóként megfordult számos országban, de rendszeres vendégelöadó volt több magyarországi és külföldi egyetemen, szakdolgozati és doktori témákat vezetett, és a tudományos közéletben is igen aktív volt. A Magyar Rovartani Társaságnak 80 éven keresztül volt tagja; a titkári, alelnöki és elnöki posztot is betöltötte, ill. a választmány rendes, később örökös tagja volt, összesen 37 éven át. 1990-ben megalapította a társaság „Rovarász Híradó” című lapját, amelynek élete végéig szerkesztőségi tagja volt. Emellett több egyéb nemzetközi és hazai szakmai civil szervezetbe is belépett. Közülük kiemelhető 
a Magyar Biológiai Társaság, melynek mintegy 70 éven át volt rendes, majd tiszteletbeli tagja, az MBT Állattani Szakosztálya előadóüléseinek pedig sok évtizeden keresztül az egyik legállandóbb, aktív résztvevője és többszörös előadója (SZÖVÉNYI et al. 2020a).

Sikeres munkásságának talán az egyik legfőbb bizonyítéka a jelentős publikációs tevékenysége. Hosszú élete során NAGY BARNABÁS 1943-tól haláláig 241 tudományos cikket, könyvfejezetet és könyvet publikált, 5 lexikon elkészítésében vett részt szócikkek megírásával, és 81 magas színvonalú tudományos ismeretterjesztő cikket is közölt, emellett számos megemlékezést, könyvismertetöt is írt (PUSKÁs et al. 2021).

Tudományos munkássága eredményeit számos kitüntetéssel ismerték el, mint például a Frivaldszky Emlékplakett ezüst és arany fokozata, a Szelényi Gusztáv Emlékérem, a Herman Ottó Díj, vagy a Magyar Érdemrend Lovagkereszt Polgári Tagozat. A tiszteletére mostanáig egy pajzstetü-, egy sáska-, egy szöcske-, két atka- és egy álkérészfajt, valamint egy csiganemet neveztek el (SZÖVÉNYI et al. 2020b).

\section{Irodalomjegyzék}

PuskÁs G., SzÖVÉnYI, G. \& SzÖCS G. 2021. Publications of Barnabás Nagy (1921-2020). (Nagy Barnabás (1921-2020) publikációi). Annales Musei historico-naturalis hungarici 112: 139-188. https://doi.org/10.53019/AnnlsMusHistNatHung.2020.112.139

SzŐCS G., SzÖVÉNYI G. \& PUSKÁs G. 2020. In memoriam: Dr. Nagy Barnabás. Agrofórum 31(9): 86.

SzÖVÉNYI G., PuSKÁS G. \& SzŐCS G. 2020a. Dr. Nagy Barnabás: egy életút az orthopterológia és a növényvédelmi rovartan vonzásában. Növényvédelem 81 (N.S. 56)(8): 381-387.

SzÖvÉNYI G., Puskás G. \& SzÖCS G. 2020b. Commemoration of Dr. Barnabás Nagy, a research entomologist on a mission to serve biodiversity and agrozoology. Acta Phytopathologica et Entomologica Hungarica 55: 197-206. https://doi.org/10.1556/038.55.2020.024 


\title{
Dr. BARNABÁS NAGY (1921-2020): born 100 years ago, died one year ago \\ GERGELY SZÖVÉNYI
}

\author{
Eötvös Loránd University, Department of Systematic Zoology and Ecology \\ Budapest, Pázmány Péter sétány 1/C, H-1117 Budapest, Hungary \\ E-mail: gergely.szovenyi@ttk.elte.hu
}

\section{ÁLLATTANI KÖZLEMÉNYEK (2021) 106(1-2): 000-000.}

\begin{abstract}
Dr. BARNABÁs NAGY passed away on 27 June 2020 at the age of 99, and now, a year later we commemorate the $100^{\text {th }}$ anniversary of his birth. His long and successful scientific career covered various fields of agro-zoology and orthopterology. At his main workplace, the Plant Protection Institute of Hungarian Academy of Sciences, where he worked for more than six decades, he dealt with several agro-entomological topics focusing on a variety of pest species of different insect orders as well as with the general approach of the pest management. Among other research topics he participated in the first attempts of the introduction of radiobiological methods into pest control, and he was one of the first researchers who published the concept of ecological plant protection as early as in 1957, decades before its wide acceptance. His contribution to the Central European orthopterology is also considerable, covering the fields of Orthoptera faunistical exploration of the territory of Hungary and the Carpatho-Pannonian region, the nature conservation and the ecology of grasshoppers. During his long career he published 241 scientific papers, books and book chapters and 81 popular scientific publications among others.
\end{abstract}

